\title{
GESTALT PSYCHOTHERAPY: SCIENCE OR QUASI-SCIENCE?
}

\author{
Jana Milić
}

\begin{abstract}
The term Gestalt appears for the first time in Gestalt psychology, created by Wertheimer, Keller, Koffka and Rubin, to mark an entity, good form. Elements do not determine an entity, and an entity is not a mere set of elements. It should be specified that a particular part of an entity is not the same when alone or included in some other entity because that part absorbs the characteristics coming from its place and function in various entities (for example, a scream in an empty street is not the same as a scream made by children playing).

The proof for gestalt therapy's success is an introspective report on subjective perception of a person's improvement, or more precisely "maintenance and development of balance and good condition of the whole organism."

To scientifically approach gestalt psychotherapy, it is necessary to operationalize positive effects or changes that this therapy brings. All terms used to validate the effects of psychotherapy are subjective constructs. An introspective perception of improvement is an indicator of a positive effect of psychotherapy. Intersubjective consent, that clients give in psychotherapy, after some time of applying gestalt therapeutic techniques results in improvement, is a guarantee that the achieved therapeutic effect is objective. Gestalt psychotherapy is a branch of psychotherapy that bases its theory on a so called "empty chair". This psychotherapeutic school's basic goals are solving the problem of the now and here, and as the other psychotherapeutic schools, it bases usually its research methods on a case study. This is clearly seen in journals and articles which discuss this psychotherapeutic school. As a therapy, it is suitable for treating mild mental disabilities and anxiety. Its therapists are constantly improving themselves and students, or psychotherapists to be, consider it to be challenging.
\end{abstract}

Acta Medica Medianae 2020;59(1):158-163.

Key words: psychotherapy, individual growth and development, work on oneself, time and man

University of Niš, Faculty of Philosophy, Psychology

Department, Niš, Serbia

Contact: Jana Milić

21/20 Pariske komune St., 18000 Niš, Serbia

Email: jana.milic.psihologija@gmail.com

\section{Introduction}

Gestalt psychotherapy is a branch of psychotherapy which bases its theory on gestalt theory, especially on Kurt Lewin's theory, and it bases its therapeutic techniques on a so called "empty chair". This psychotherapeutic school's basic goals are solving the problems of the here and now, and as other schools of psychotherapy, it usually bases its fundamental methods on the analysis of a case. That is clearly seen in journals and articles which discuss this psychotherapy school.
Historically speaking, gestalt therapy was created by Fritz Perls in 1942. The practitioners of this branch of psychotherapy are Laura Perls, Yontef, Zinker, as well as the Parisian's gestalt school practitioners, such as Gonzague Masquelier, Brigitte Martel, Giles Delisle from Montreal and Edoardo Giusti from Rome. Considering that this branch of psychotherapy has its main support in the gestalt theory, we will mention only the key concepts and principles of this theory.

The Basic Scientific Principles in Gestalt Theory and Psychotherapy

Beginning with Descartes, it was thought if we would want to objectively comprehend and analyze a phenomenon or behavior, then we would need to find their causes which are usually found in the past. Causal determination is based on connecting the past events and their current consequences. Once we see the cause of a phenomenon, then it becomes predictable for us and we can control it.

However, contemporary physicians want us to understand there is no such thing as an "objective" analysis because a mere observation of a phenomenon changes it, and predict the most of the 
causes is found in the future! (For instance: I went to bed earlier last night so that I would be well rested today as I could teach an important class, so, the cause is in the future), says Ginger (1). This only proves that theological determination and explanation by comprehension have always been present in psychology, since the ancient division of psychology to a natural science and a spiritual science. Where do gestalt theory and psychotherapy belong to? What kind of determination it deals with?

In the beginning of the development of this psychological movement, the object of analysis was the observation or the laws under which observation was constructed. The laws of organizing stimuli into observation have been experimentally proven and verified. Hereby the disciples of this school in psychology have chosen an original approach to access perception, as a phenomenon which is dynamic, not static, organized, not chaotic, predictable, but not unexpected. The term Gestalt is a term which appears for the first time in Gestalt psychology founded by Wertheimer, Keller, Koffka and Rubin, to signify a whole, good form. Elements do not determine a whole, and a whole is not a mere set of elements. It should be said that a particular part of a whole is not the same when alone or included in some other whole, because that part gets the characteristics coming from its placement and its role in various wholes (for example, a scream in an empty street is not the same scream of children who play together).

Disciples of gestalt school in psychology started off with a radically new approach to phenomenology of observation, which are then experimentally tested and confirmed, thus making a significant step in comparison to theories which had dealt with perception until then. These principles (the significance of restructuration of the observational field-figures and backgrounds, significance of nearness, similarity, good form and common faith) found while explaining and understanding the processes of observation were generalized as other cognitive processes, whereas their followers to psychotherapy.

When we speak about "Gestalt psychotherapy", we emphasize that gestalt psychotherapists consider that a man's behavior cannot be understood outside of the context it is developed in, the context of the field.

a) Field is a scientific construct which the disciples of the gestalt principle in psychology and psychotherapy rely on. It refers to the notion that life is an open system in which there is interaction between organisms and environment. An organism is an active participant in the creation of its own reality and can be the basic force in shaping our experience. Perls thought that a man and his behavior cannot be understood out of context in which the behavior is being developed $(2,3)$. We are the people in context! and here.

b) Dialogue-Me: You conversation, the now

c) Phenomenology-stretches towards the understanding based on what is obvious or what is discovered by the situation itself, but not on interpretation of an observer (3).
Apart from these terms, according to Ginger's systematization there are 20 more constructs of gestalt therapy and they are:

1) The now and how,

2) Process,

3) Awareness,

4) The limits of contact,

5) The field and system,

6) Creative adaptation,

7) The experience cycle,

8) Unfinished businesses/ Unfinished gestalt,

9) Resistance,

10) Homeostasis,

11) The Potentiation of responsibility,

12) Experimentation,

13) The right on diversity-unrepeatability of every man,

14) The Attitude for sympathy,

15) The Holistic approach to a man,

16) The Polarities which complete each other,

17) The Involvement of emotions and body,

18) Aggression,

19) Creativity and imagination,

20) Individual inside a group.

\section{diagnostics \\ The effects of gestalt psychotherapy and}

Proving the success of gestalt therapy is an introspective statement on impressions of the subjective better in a person, or more precisely "maintaining and developing balance and good condition of the whole body. Health is not just the absence of a disease or defect, but the condition of a complete physical, mental and social wellness" (1).

This principle, as Ginger (1) puts it in his book, states that Gestalt therapy's task is not treatment but maintaining balance and wellness of the whole organism, leads to the "rejection" of discussing normality and disorder which opposes Van Baalen's statement, the author of the article "Gestalt diagnosis" from 1999, which is about finding the appropriate diagnostic criteria for evaluation of the severity and gravity of a patient's psychopathology (4).

In his article, Van Baalen (4) gave detailed instructions on the criteria to use before diagnosing. He accurately explained the theory of Gestalt psychotherapy, trying to be very specific so that the reader truly understands the interaction among parts within the field, in the way that the sense of the figure and background is that every figure has its own background, and that sometimes it can happen for the background to be primary and stand out, or that these two (the figure and background) change in accordance with the focus. He also described the role of a therapist as the part which engages into interaction within a field with a client. The accent is on the change (behavioral or emotional) in a client, which would be closely related to Fajgelj (5), a methodologist, whose theory is about wrong patterns in behavior that change through relations, which would be closely related to psychology's task classified as a behavioral science. The scientific value of the article is high, given the fact it gives directions to Gestalt therapists in understand- 
ing the process of diagnosing while being closely connected to the clinical practice of psychology.

Baalen's theory is very similar to Mann Dave's (6) theory, which states that a good Gestalt is clear, or the relation between the figure and background is clear, that is, between a primary need and the background, hence the energy flow which every person should have in a certain moment depends on the dominant need.

The founding source of pathology, according to Gestalt, is the incomplete emotional Gestalt or the "unfinished business" (2).

To scientifically approach gestalt psychotherapy, it is needed to operationalize positive effects or changes which this therapy provides. All the terms which validate the effect of psychotherapy are subjective constructs. The introspective perception of improvement is the indicator of the positive effect in psychotherapy. Intersubjective consent, that clients give in psychotherapy, after some time of applying gestalt therapeutic techniques results in improvement, is a guarantee that the achieved therapeutic effect is objective. The generality of these findings, their systematic record and evaluation, as well as the development of application and methods, confirm Ginger's and Van Baalam's scientific approach.

\section{Gestalt psychotherapy in scientific journals and articles}

According to the data in KoBSON database, there is a journal that publishes articles about Gestalt psychotherapy. It is the journal called South African Journal of Psychology. The journal is not strictly related to the field of Gestalt psychotherapy, as British Gestalt journal, but it publishes numerous articles about Gestalt psychotherapy. It is found by using the key words gestalt psychotherapy.

Susanne Jacobs often publishes her articles in this journal. In her articles she always refers to the founders of Gestalt psychotherapy, Yontef and Zinker, which would imply she doesn't digress from the primary theory and the methods of Gestalt psychotherapy, and is consistent in maintaining the tradition (7). Her article which deals with humor in Gestalt therapy consistently follows the theory of Gestalt therapy. The method of the research is the case study, which belongs to the clinical method but the author has precisely explained the science behind this method, referring to various authors who use it in their research. Susanne states that the facts will be collected before and after a treatment, gestalt theory will be consistently applied in practice and that the method of observation will be used. The author defined a theory which will be applied, illustrated to the details the method which will be used and systematically showed the results of the observation, that is, the case study. The article is consistent in following scientific methodological norms by applying the Gestalt theoretical approach, describes detailed observations so that the process could be checked. Her work is quite close to a scientific approach, which separates her greatly from many other researchers in the field hence many authors refer to and quote her. This is an extraordinary example how a serious scientific methodology could be applied to a field of psychotherapy, which by its nature belongs on the border between science and pseudoscience.

The reference Susanne uses is the book Skills in Gestalt Counselling and Psychotherapy by authors Joyce i Sills (8). The book describes how to lead the Gestalt session and operate with the terms related to religion. One part of the book is about the difference between a normal condition and a transcendental experience and esoteric, describes how a man regresses to the level of an infant, has psychotic reactions, and even can be autistic. Religion does not have an empiric proof. Various religions are founded on a religious experience of an individual, and are characterized by the feeling of admiration for God. The main controversy between various representatives of materialism and religion lies beyond the borders of experimental, verifiable, and refers to the issue of the genesis of the universe. Materialists claim that the universe is endless in space and time, and numerous religions consider the universe has its own Maker, whom not even the greatest minds, such as Einstein, renounced. He explains that his religion is based on the belief of a Higher reason's existence, who reveals itself in the world available for cognition (9). However, if the meanings of numerous mentioned terms (esotery, transcendental experience, religion, deity) are understood from the point of view we have nowadays, Gestalt therapy in this case, approached by Joyce and Sills, is not a science.

Valerie Aiach Dominitz following the theory of Gestalt psychotherapy applied in the practice of the case study (10). The terms are defined and explained as well as the work with a client. Therefore, this journal publishes articles about Gestalt psychotherapy. Among its authors, we can encounter the founders of Gestalt therapy and Zinker, Yontef, Perls.

In his article published in Gestalt Journal, Edwin S. Hariss, describes the attitude towards God and disease (11). The article is not consistent in following the norms of Gestalt psychotherapy. The method is based on an experiment in which one speaks to God and gives the answer to oneself from God's perspective. The therapy is conducted with abused clients and those angry with God. A man's world is spiritual, immaterial; spiritual being here defined as recognizing the reality greater than the one which is a convulsion of all visible things. Edwin S. Hariss says that Gestalt psychotherapy is more and more in collaboration with psychoanalysis, which Karl Poper does not consider to be a science because it does not provide the refutation, that is, from the beginning it was untrusting and in a mythical way approaches to behaviour (12).

Yontef in British Gestalt Journal points out that Gestalt therapy has founded many useful and creative innovations related to theory and practice in psychotherapy (13). Kohler (1959 cited by Yontef, 1996) confirms that. He states that enthusiasm and ventures of the early Gestalt's psychologists were virtues because they created new observations and discoveries. Moreover, Yontef says that many of 
these discoveries and techniques are integrated into the general practice, many times with no credit. However, Gestalt techniques and methods represent a good model of psychotherapy and should be applied and developed forwardly.

Some articles are about the connection between Gestalt psychotherapy, existentialism and Zen Buddhism. Existentialist narrowness results in noogenic neuroses (Frankl, 1994) which imply overaccented existential frustration, which disrupts free action and development. It can lead to alienation ("My mind contradicts my feelings", a quote from the novel "The Stranger" by Albert Camus). This narrowness is called "the existential vacuum" which refers to the lack of sense or the state of boredom. Since Frankl's logotherapy represents therapy involving sense, then the constant frustration disrupts sense. The greatest sense of a man's existence is love.

Cannon Bard studied philosophy while studying Gestalt therapy (14). She thought that the Sartre's existential philosophy could be connected to Gestalt therapy. Her opinion is that Gestalt therapy can learn a great deal from existentialists about anxiety. Existentialist psychotherapy still did not find its Freud. She relied on and supported the work of Frederick Fritz Perls and having compared existentialist and gestalt psychotherapy, said that both deny the Freudian unconscious, whereas unconscious in their sense is a phenomenological relation between consciousness and its objects. The fundamental thread which connects them is the sense of emptiness (there is nothing there). That would be the idea of Zen Buddhism, and Perls was a student of Zen. "There is nothing but happenings, that is, things happen". Neurotic people cannot see, because their eyes are always given to others so to reflect themselves as objects (Cannon, 2009). Freedom is nothing, emptiness, detachment from things, the sense of emptiness, but Kant says there where the sense of emptiness is, is God. The scientific value of the article is funded on pointing out the clear similarities between Sartre's existential philosophy and Gestalt therapy. The similarity is the sense of emptiness- unreality.

In her article, Gestalt Therapy in Psychological Practice, Palmer A. Kendra discusses "phenomenological" or "experienced" approach, which relates to a patients' experience-the way he or she experiences things (15). Phenomenology is a discipline that helps patients digress from their usual way of thinking so they could make a difference between what they are really experiencing at the moment and what is a consequence of the past events (Yontef, 1993, cited by Palmer, 2011). Therapy, phenomenological and existential, focuses on people's existence-relationships with others, joys and sufferings, and for example, immediate experience. Patients have freedom, but they are given the responsibility for their actions and thoughts. The challenge is to take responsibility for themselves in the present (Corey, 2009: cited by Palmer, 2011). Patients' specific reality is under research, while the diagnosis and prognosis are mainly ignored (Corey, 2009, cited by Palmer, 2011).

Gestalt therapy is efficient (16). This is a positive, humanistic therapy. It helps practitioners (both clients and therapists) become responsible for their own experiences and experiment with new ways of behaviour and thinking. It helps them practice and completely experience key moments and emotions in their lives (17). Awareness about important topics or patterns urges practitioners and clients to become more authentic and open for transition or change.

Many articles talk about the significance of the connection between Gestalt psychotherapy and meditation. Meditation (of the eastern religion) is equal to praying in a Christian religion. One who meditates, thinks about a particular content, goes deep in thoughts or strives to achieve relaxation using a breathing method. To hear and accept a prayer cannot be considered scientific.

\section{Conclusion}

Since its inception, Gestalt therapy, until today, has evolved into psychotherapy which field of interest is open to religion, meditation, play therapy, psychoanalysis, but primarily its concepts were based on understanding an individual's existence and it used the phenomenological method. So, the description of experience of the here and now. It could be said it is not rigid in relation to other psychoterapies' points of view and allows combining and eclecticism. What I have noticed is that the authors of the articles are always relying on the founders of Gestalt psychotherapy, Perls, Yontef, Zinker, which would imply that theoretical basis of psychotherapy should not be changed. The methodology of Gestalt psychotherapy is based on constructs of the gestalt theory; the principles of causability are manifested in therapeutic situation or field, whereas change in one part of the field causes changes in other parts of the field. The truth it strives for is the patient's truth. Gestalt psychotherapy confirms itself through the subjective better in a patient, that is, in a way a kind of a measurable subjective experience. Nowadays it establishes connection to religion for what there are no facts for proof. That would be the step backwards in science.

Gestalt psychotherapy, in general, does not belong to a scientific field exactly because of the narrower connection to religion and meditation, but of course, it is possible to advance the methodology of verification and measure the effects of psychotherapy. In that sense, the gap, scientifically and pseudonically does not have to be that deep, at least when it is about gestalt psychotherapy, given that the theory which is based on experimental research of perception and possibility to explicitly define at least some, if not all, parameters of improvement which therapy can give to a person, that is, to people. 


\section{References}

1. Ginger S. Gestalt Psychotherapy: The Art of Contact. Novi Sad: Psihopolis institute; 2010.

2. Perls F, Hefferline R, Goodman R. Gestalt therapy integrated: Excitement and growth in the human personality. New York: Dell; 1951.

3. Erić LJ. Psychotherapy. Belgrade: University of Medicine; 2002.

4. Van Baalen D. Gestalt Diagnosis. Oslo: Norsk Gestaltinstitutt; 1999.

5. Fajgelj S. The Observational Methods of Behavior. Belgrade: The Centre of Applied Psychology; 2004.

6. Mann D. Gestalt Therapy-100 Key Point and Techniques. Abingdon USA: Taylor \& Francis Group; 2010. [CrossRef]

7. Jacobs S. Humour in Gestalt Therapy - Curative Force and Catalyst for Change: A Case Study. S Afr ] Psychol 2009;39(4):498-506. [CrossRef]

8. Joyce $P$, Sills C. Skills in Gestalt Counselling and Psychotherapy. London: Sage; 2001. [CrossRef]

9. Menj A. The History of Religion. Belgrade: Plato; 2005.

10. Dominitz AV. Gestalt Therapy Applied: A case study with an Inpatient diagnosed with Substance use and bipolar disorders. Clin Psychol Psychother 2017;24(1): 36-47. [CrossRef] [PubMed]

11. Harris ES. God, Buber, and the Practice of Gestalt Therapy. The Gestalt Journal 2000;23(1):39-62.

[CrossRef]

12. Milas G. Research Methods in Psychology and Other Social Sciences. Zagreb Jastrebarsko: Naklada slap; 2005.

13. Yontef G. Supervision from a Gestalt therapy perspective. BG] 1996;5(2):92-102. [CrossRef]

14. Cannon B. Nothingness as the Ground for Change Gestalt Therapy and Existential Psychoanalysis. Existential Analysis 2009; 20(2):192-210.

15. Palmer KA. Gestalt Therapy in Psychological Practice. Inquiries Journal/Student Pulse 2011;3(11). [CrossRef]

16. Benjafield GJ. Revisiting Wittgenstein Köhler and Gestalt psychology. J Hist Behav Sci 2008;44(2):99118. [CrossRef] [PubMed]

17. Frankl Viktor E. Why do not You Commit Suicide? Belgrade: Prosveta; 1994. 


\title{
GEŠTALT PSIHOTERAPIJA: NAUKA ILI KVAZINAUKA?
}

\author{
Jana Milić
}

Univerzitet u Nišu, Filozofski fakultet, Departman za psihologiju, Niš, Srbija

Kontakt: Jana Milić

Pariske komune 21/20, 18000 Niš, Srbija

E-mail: jana.milic.psihologija@gmail.com

Pojam geštalt je pojam koji se prvi put pojavljuje u geštalt psihologiji, čiji su stvaraoci Verthajmenr, Keler, Kofka i Rubin, kako bi označio celinu, dobru formu. Elementi ne determinišu celinu, a celina nije puki zbir elemenata. Treba naglasiti $i$ to da određeni deo unutar neke celine nije isti deo kada je izdvojen ili kada je uključen u neku drugu celinu, jer taj deo poprima osobine koje proizilaze iz njegovog mesta i njegove uloge u različitim celinama (npr. vriska u pustoj ulici nije isto što i vriska dece koja se igraju).

Dokaz o uspešnosti geštalt terapije je introspektivni izveštaj o doživljaju subjektivog boljitka kod osobe ili preciznije rečeno "održavanje i razvijanje ravnoteže i dobrog stanja celog organizma". Za naučni pristup geštalt psihoterapiji potrebno je operacionalizovati pozitivne efekte ili promene koje ova terapija donosi. Svi termini kojima se validiraju efekti psihoterapije subjektivni su konstrukti. Introspektivni doživljaj boljitka pokazatelj je pozitivnog efekta psihoterapije. Intersubjektivna usaglašenost klijenata, koji su na psihoterapiji, da posle izvesnog vremena, uz primenu geštalt terapijskih tehnika osećaju poboljšanje, jeste garancija da je postignuti terapijski efekat objektivan. Geštalt psihoterapija je grana psihoterapije koja svoju teoriju bazira na geštalt teoriji i to pre svega na teoriji polja, a svoje terapijske tehnike zasniva na tzv. praznoj stolici. U okviru ovog psihoterapisjkog pravca, bazični ciljevi su usmereni na rešavanje problema sada $i$ ovde, a kao i ostale psihoterapijske škole, svoje istraživačke metode bazira uglavnom na studiji slučaja. To se jasno vidi u časopisima i člancima u kojima se razmatra ova psihoterapijska škola. Kao terapija, pogodna je za lečenje blagih mentalnih poremećaja i anksioznosti. Njeni terapeuti konstantno napreduju, a učenici ili budući psihoterapueti smatraju je izazovnom.

Acta Medica Medianae 2020;59(1):158-163.

Ključne reči: psihoterapija, individualni rast i razvoj, rad na sebi, vreme i čovek 